\title{
A new highly specific and robust yeast androgen bioassay for the detection of agonists and antagonists
}

\author{
Toine F. H. Bovee • Richard J. R. Helsdingen • \\ Astrid R. M. Hamers • Majorie B. M. van Duursen • \\ Michel W. F. Nielen • Ron L. A. P. Hoogenboom
}

Received: 27 April 2007 /Revised: 3 July 2007 / Accepted: 15 August 2007 / Published online: 12 September 2007

(C) Springer-Verlag 2007

\begin{abstract}
Public concern about the presence of natural and anthropogenic compounds which affect human health by modulating normal endocrine functions is continuously growing. Fast and simple high-throughput screening methods for the detection of hormone activities are thus indispensable. During the last two decades, a panel of different in vitro assays has been developed, mainly for compounds with an estrogenic mode of action. Here we describe the development of an androgen transcription activation assay that is easy to use in routine screening. Recombinant yeast cells were constructed that express the human androgen receptor and yeast enhanced green fluorescent protein (yEGFP), the latter in response to androgens. Compared with other reporters, the yEGFP reporter protein is very convenient because it is directly measurable in intact living cells, i.e., cell wall disruption and the addition of a substrate are not needed. When yeast was exposed to $17 \beta$-testosterone, the concentration where half-maximal activation is reached $\left(\mathrm{EC}_{50}\right)$ was $50 \mathrm{nM}$. The relative androgenic potencies, defined as the ratio between the $\mathrm{EC}_{50}$ of $17 \beta$-testosterone and the $\mathrm{EC}_{50}$ of the compound, of $5 \alpha$-dihydrotestosterone, methyltrienolone, and $17 \beta$-boldenone are $2.3,1.4$, and 0.15 respectively. The results presented in this paper demonstrate that this new yeast androgen bioassay is fast, sensitive, and
\end{abstract}

T. F. H. Bovee $(\bowtie)$ • R. J. R. Helsdingen · A. R. M. Hamers •

M. W. F. Nielen $\cdot$ R. L. A. P. Hoogenboom

RIKILT, Institute of Food Safety,

Wageningen University and Research Center,

P. O. Box 230, 6700 AE Wageningen, The Netherlands

e-mail: toine.bovee@wur.nl

M. B. M. van Duursen

IRAS, Institute for Risk Assessment Sciences, Utrecht University,

P. O. Box 80177, 3508 TD Utrecht, The Netherlands very specific and also suited to detect compounds that have an antiandrogenic mode of action.

Keywords Antagonists · Brominated flame retardants . Crosstalk $\cdot$ Metabolism $\cdot$ Receptor $\cdot$ Saccharomyces cerevisiae

\section{Introduction}

There is concern that chemicals in our food, water, and environment affect human health by disrupting normal endocrine function, possibly leading to reproductive failure in humans and tumors in sensitive tissues [1,2]. This relates to chemicals with previously unknown hormonal properties, like certain pesticides and plasticizers, but also to compounds used in pharmaceutical preparations, eg., oral contraceptives and tablets for hormone-replacement therapy, the endogenous steroids excreted in urine of man and domestic animals and potentially also compounds used for their growth-promoting properties in animals. Of all endocrine disruptors, environmental estrogens are the most studied [3]. However, recent studies show a crucial involvement of the androgen receptor in abnormal sex development. The presence of pollutants with adverse effects on human androgen receptor (hAR) has been reported from paper-mill effluents and as a result of intensive farming $[4,5]$. Xenoandrogenic exposure-related disorders include testicular cancer, hypospadias, cryptorchidism, and poor sperm and very recently prepubertal gynecomastia was linked to both estrogenic and antiandrogenic effects of lavender and tea tree oil [6].

Chemical and immunological methods are commonly used to detect steroid hormones in food, clinical practice, environmental samples, or doping control. Owing to the 
great variety of chemicals with hormonelike activity, these methods have the drawback that they only quantify the compound of interest and are not able to determine biological activity of unknown compounds and their metabolites, this in contrast to biological assays. Receptorbased transcription activation assays can be used to detect all compounds having affinity for a given receptor $[7,8]$. In contrast to receptor binding assays, receptor gene bioassays also include the transactivation step and can distinguish between receptor agonists and receptor antagonists [9]. This feature is very helpful in detecting both known and unknown compounds.

Several assays have been developed for this purpose, using both mammalian and yeast cells. In general, transcription activation assays based on mammalian, or more particular human, cell lines have been shown to be more sensitive than yeast-based assays, and may be able to identify compounds that require human metabolism for activation into their active state. Metabolic conversion can either activate or inactivate some compounds [10], whereas the relatively low metabolic capacity of yeast ensures that the test reflects the activity of the original compound. In addition, yeast-based assays have several other advantages. These include low costs, easy handling, lack of known endogenous receptors that may compete with the receptor activity under investigation (no crosstalk), and the use of media that are devoid of steroids [11-13]. Furthermore, yeast cell assays are extremely robust and survive extracts from dirty sample matrices such as sediments, urine, and feed [14-16]. Especially in the case of androgens, the lack of known endogenous receptors in yeast is a great advantage compared with mammalian cell lines, as androgen responsive elements (AREs) can also be activated by the progesterone receptor and the glucocorticoid receptor. To avoid potential crosstalk in mammalian cell lines, a lot of efforts was expended to construct an ARE that is specific and no longer inducible by the progesterone and glucocorticoid receptor [17-19]. However, up till now such an ARE does not exist and it is doubtful whether it will be found, as the consensus progesterone responsive element/glucocorticoid responsive element is equal to the consensus ARE. Moreover, the glucocorticoid receptor is normally expressed in all mammalian cell types. So far this has resulted in cell lines that are not specific for androgens and that also respond to gestagens or glucocorticoids [20-22].

This paper reports the development of a new yeast androgen bioassay by creating a stably transfected yeast strain that expresses yeast enhanced green fluorescent protein (yEGFP) as a measurable reporter protein in response to androgens. The lack of known endogenous receptors in yeast enabled us to use the strong nonspecific consensus ARE sequence, which is actually a common hormone responsive element that is recognized by the androgen, progesterone and glucocorticoid receptors and can therefore not be used in mammalian cell lines expressing more than one of these receptors. Exposures to $17 \beta$-testosterone, $17 \beta$-estradiol, progesterone, dexamethasone, and other compounds were performed in 96-well plates in order to demonstrate the suitability and specificity of this new yeast androgen bioassay. Additionally, flutamide and several brominated flame retardants were tested for their antagonistic mode of action and the results were compared with a yeast androgen bioassay expressing $\beta$ galactosidase as a reporter protein.

\section{Materials and methods}

\section{Chemicals}

Chemicals and methods to prepare the growth media, to perform PCR, to isolate DNA, and to transform bacteria and yeast were as described earlier [23]. Corticosterone, dexamethasone, $17 \alpha$-estradiol, $17 \beta$-estradiol, estrone, flutamide, 4-hydroxytamoxifen, medroxyprogesterone 17 -acetate, and progesterone were obtained from Sigma (St. Louis, MO, USA). The following compounds were obtained from Steraloids (Newport, RI, USA): 17 $\beta$-boldenone, diethylstilbestrol, $5 \alpha$-dihydrotestosterone, $17 \alpha$-ethynylestradiol, $17 \beta$ testosterone and $17 \beta$-trenbolone. Tetrahydrogestrinone (THG) was a gift from M. Thevis (DSHS, Cologne, Germany). Copper sulfate and dimethyl sulfoxide (DMSO) were obtained from Merck (Darmstadt, Germany) and methyltrienolone was obtained from PerkinElmer (USA). All restriction endonucleases and corresponding buffers were obtained from New England Biolabs (Hitchin, UK) and the yeast $\beta$-galactosidase assay kit was from Pierce Biotechnology (Rockford, IL, USA). 2,4,6-Tribromophenol (TBP), BDE-39, and the hydroxyl derivative 4-OH-BDE-17 were synthesized at the Wallenberg Laboratory (Stockholm University, Sweden).

\section{Yeast strains}

The yeast Saccharomyces cerevisiae (CEN.PK 102-5B, $\mathrm{K} 20, U_{R A 3^{-}}, H I S 3^{-}, L E U$ ) host strain was a gift from $\mathrm{H}$. Silljé (University of Utrecht, The Netherlands). The yeast androgen bioassay with $\beta$-galactosidase as a marker was kindly provided by D.P. McDonnell (Duke University, USA).

Plasmids

The p403-GPD and p406-CYC1 yeast expression vectors were obtained from the American Type Culture Collection (ATCC, Rockville, Maryland, USA). The pyEGFP3 plasmid was a gift from A.J. Brown (Stanford University, USA). 
Construction of the p403-GPD-hAR expression vector

The yeast cells provided by McDonnell were grown overnight and chromosomal DNA was isolated. This DNA was used to serve as a template for the PCR to obtain the complementary DNA (cDNA) of hAR. Full-length hAR cDNA was obtained using the Expand High Fidelity PCR system (Boehringer Mannheim) and an Eppendorf Mastercycler gradient. The sequence of the 5'-primer was 5'GCTCTAGAATGGAAGTGCAGTTAGGGCTGGG-3', containing a restriction site for $X b a \mathrm{I}$ just before the ATG start codon. The sequence of the 3'-primer was 5'GCGGATCCTCACTGGGTGTGGAAATAGATGGG-3', containing a restriction site for BamHI just after the TGA stop codon. This PCR generated a full-length doublestranded (ds) cDNA of 2,763 bp of the hAR gene with a 5'$X b a \mathrm{I}$ and a $3^{\prime}$-Bam $\mathrm{HI}$ restriction site.

The 2,763-bp full-length hAR PCR product was isolated from a 1\% low-melt agarose gel, cleaved with $X b a \mathrm{I}$ and BamHI and ligated into the corresponding site of the p403GPD yeast vector. Plasmid digestion and PCR controls revealed several good clones.

Construction of the p406-ARE 2 -CYC1-yEGFP reporter vector

A set of complementary oligonucleotides ( $a$ and b), each with two consensus ARE sequences (in bold), were synthesized. A solution with both cDNA oligonucleotides, $2.5 \mu \mathrm{M}$ of each, was heated at $95^{\circ} \mathrm{C}$ and cooled down to room temperature in $2 \mathrm{~h}$. This set gave a ds DNA with a 5'SacI sticky end and a 3'-MscI blunt end.Sa: 5'-AAAGTC AGAACAGCATGTTCTGATCAAATCTAGAAGATC CAAAGTCAGAACAGCATGTTCTGATCAAACTC G A G C A G A T C C G C C A G G C G T G TATA T A T A GCGTGGATGG-3'Sb: 5'-CCATCCACGCTATATATA CACGCCTGGCGGATCTGCTCGAGTTTGATCAGAA CATGCTGTTCTGACTTTGGATCTTCTAGATTTGAT CAGAACATGCTGTTCTGACTTTAGCT-3'.

This ds DNA was cloned into the corresponding site of the p406-CYC1 vector. Subsequently, yEGFP [24] obtained from a HindIII/SalI double digestion of pyEGFP was cloned in the corresponding HindIII/SalI sites of the p406-ARE ${ }_{2}-C Y C 1$ reporter construct. Plasmid digestion and PCR controls revealed several good clones.

Transformation of yeast cells

Transformation of yeast $\mathrm{K} 20$ host strain ( $\mathrm{Ura}^{-}$, $\mathrm{His}^{-}$, and $\mathrm{Leu}^{-}$) was performed by the lithium acetate protocol as described earlier [23]. First, the yeast was transformed with the $\mathrm{p} 406-\mathrm{ARE}_{2}-C Y C 1-\mathrm{yEGFP}$ reporter vector, integrated at the chromosomal location of the uracil gene via homologous recombination. Therefore, prior to transformation, the reporter vector was linearized by cutting with $S t u \mathrm{I}$, which has a unique restriction site in the URA3 marker gene. Transformants were grown on minimal medium plates containing L-leucine and L-histidine (MM/L plates). This yeast reporter strain was then transformed with the p403GPD-hAR expression vector, which was linearized by cleavage with $N s i$, which has a unique restriction site in the HIS3 marker gene (histidine). Transformants were grown on $\mathrm{MM} / \mathrm{L}$ plates and PCR controls were used to select clones that contain the p406-ARE 2 -CYC1-yEGFP reporter and the p403-GPD-hAR expression construct.

PCR controls

PCR controls were performed on the reporter-receptor transformants. Yeast chromosomal DNA of transformants was isolated and PCR controls were performed. PCR I was performed with a 5'-primer on the backbone of the reporter plasmid and a 3'-primer on the $\mathrm{ARE}_{2}$ sequence. The sequence of the 5'-primer was 5'-AGCGAGTCAGTGAGCGAGGAAG-3' and the sequence of the $3^{\prime}$-primer was 5'-TGCTGTTCTGACTTTGGATC-3'. PCR II was performed with a $5^{\prime}$-primer on the $\mathrm{CYCl}$ (cytochrome c oxidase) promoter of the reporter plasmid and a $3^{\prime}$-primer on the CYC1 terminator. The sequence of the 5'-primer was 5'-TCTATAGACACACAAACACAA-3' and the sequence of the 3'-primer was 5'-GGGAGGGCGTGAATGTAAG-3'. PCR III was performed with the primers that were also used to obtain the full length cDNA of the hAR (see "Construction of the p403-GPD-hAR expression vector").

Streamlined yEGFP assay with the yeast androgen bioassay

The day before running the assay, a single colony from a $\mathrm{MM} / \mathrm{L}$ agar plate was used to inoculate $10 \mathrm{~mL}$ of the selective $\mathrm{MM} / \mathrm{L}$ medium. This culture was grown overnight at $30{ }^{\circ} \mathrm{C}$ with vigorous orbital shaking. At the late $\log$ phase, the yeast androgen receptor biosensor was diluted in the selective $\mathrm{MM} / \mathrm{L}$ medium to an optical density (OD) at $604 \mathrm{~nm}$ between 0.08 and 0.12 . For exposure, aliquots of $200 \mu \mathrm{L}$ of this diluted yeast culture were pipetted into each well of a 96 -well plate and $2 \mu \mathrm{L}$ of a $17 \beta$-testosterone or other stock solution in DMSO was added. DMSO-only controls were included in each experiment and each sample concentration was assayed in triplicate. Exposure was performed for $24 \mathrm{~h}$ at $30{ }^{\circ} \mathrm{C}$ and orbital shaking at $125 \mathrm{rpm}$. Fluorescence was measured at 0 and $24 \mathrm{~h}$ directly in a CytoFluor multiwell plate reader (Series 4000, PerSeptive Biosystems) using excitation at $485 \mathrm{~nm}$ and measuring emission at $530 \mathrm{~nm}$. The fluorescence signal was corrected with the signals obtained with $\mathrm{MM} / \mathrm{L}$ containing DMSO solvent only. Densities of the yeast culture were determined by measuring the OD at $630 \mathrm{~nm}$, but this 
was only done to check whether a sample was toxic for the yeast cells. For the calculation of the relative androgenic potency (RAP) of the compounds in the yeast androgen bioassay, the data of a complete dose-response curve were fitted using the equation $y=a_{0} /\left[1+\left(x / a_{1}\right)^{a_{2}}\right]$ (Slide write Plus, version 6.00). This is equivalent to response $=$ max imum response - minumum response $/$ $\left[1+\left([\text { agonist }] / E C_{50}\right)^{\text {width of transition }}\right]$, where response is the measured fluorescence signal, [agonist] is the concentration of the test compound, and $\mathrm{EC}_{50}$ is the concentration of the test compound giving half-maximum response.

lacZ-based yeast androgen bioassay: $\beta$-galactosidase assay

An agar plate containing the selective growth medium, consisting of a yeast nitrogen base with dextrose $(2 \%)$, lysine $(36 \mathrm{mg} / \mathrm{L})$, tryptophan $(48 \mathrm{mg} / \mathrm{L})$, uracil $(24 \mathrm{mg} / \mathrm{L})$, and adenine $(41 \mathrm{mg} / \mathrm{L})$, was inoculated with the yeast androgen receptor cytosensor from a frozen $-80{ }^{\circ} \mathrm{C}$ stock $(20 \%$ glycerol $\mathrm{v} / \mathrm{v})$. The plate was incubated at $30{ }^{\circ} \mathrm{C}$ for 24-48 $\mathrm{h}$ and then stored at $4{ }^{\circ} \mathrm{C}$. The day before running the assay, a single colony of the yeast was used to inoculate $10 \mathrm{~mL}$ of the selective growth medium. This culture was grown overnight at $30{ }^{\circ} \mathrm{C}$ with vigorous orbital shaking at $225 \mathrm{rpm}$. At the late log phase, the yeast androgen receptor cytosensor was diluted in growth medium to an OD of 0.06 at $604 \mathrm{~nm}$, and $\mathrm{CuSO}_{4}(0.05 \mathrm{mM})$ was added to induce the expression of the hAR. For exposure in 96-well plates, aliquots of $200 \mu \mathrm{L}$ of this diluted yeast culture were pipetted into each well and $2 \mu \mathrm{L}$ of stock solutions in DMSO was added. Exposure was performed for $24 \mathrm{~h}$ at $30{ }^{\circ} \mathrm{C}$ and $125 \mathrm{rpm}$, and the $\beta$-galactosidase activity was measured with a commercial yeast $\beta$-galactosidase assay kit from Pierce (Rockford, IL, USA). This kit uses $o$-nitrophenyl $\beta$ D-galactopyranoside as a substrate, and the solution turns yellow upon hydrolysis of $\beta$-D-galactopyranoside to $o$ nitrophenol and galactose. The yellow $o$-nitrophenol is measured in a Biotek (Winooski, VT, USA) model ELx 808 series ultra microplate reader at $405 \mathrm{~nm}$. Densities of the yeast culture were determined by measuring the $\mathrm{OD}$ at $630 \mathrm{~nm}$. The measured response at $405 \mathrm{~nm}$ was corrected for the $\mathrm{OD}$ at $630 \mathrm{~nm}$.

\section{Results and discussion}

A recombinant yeast cell was constructed that expresses the hAR and yEGFP as a reporter protein in response to androgens. Both the receptor construct as well as the reporter construct were stably integrated into the yeast genome by the use of yeast-integrating plasmids. For the construction of the reporter vector the p406-CYCl plasmid, containing the URA3 marker gene, was used. Two consensus AREs were placed in the $S a c \mathrm{I} / \mathrm{Msc}$ I site of the truncated $C Y C 1$ promoter in a way that the -254 to -147 $X h o \mathrm{I}-S p h \mathrm{I}$ part of the $\mathrm{CYCl}$ promoter was restored [23]. High expression levels of the androgen receptor were obtained by placing the cDNA of the hAR gene behind the strong constitutive yeast glyceraldehyde-3-phosphate dehydrogenase (GPD) promoter in the p403-GPD plasmid. This plasmid contains the HIS3 marker gene. Transfected strains were checked with PCR. The correct and specific functioning of the yeast androgen bioassay was studied by exposures to $17 \beta$-testosterone and other compounds and the results were compared with results obtained with the lacZbased yeast androgen bioassay provided by McDonnell. In addition, the antiandrogenic properties of several brominated flame retardants were investigated.

\section{PCR controls}

A number of different PCR controls were carried out to check the integration of the vectors into the yeast genome. Figure 1 shows the gel electrophoresis results of these PCR controls. PCR I (Fig. 1a) was performed with primers on the backbone of the p406 plasmid and on the $\mathrm{ARE}_{2}$ sequence. As expected, it gave the specific 360-bp band with the p406-ARE $E_{2}-C Y C 1$-yEGFP reporter vector and the DNA that was isolated from the yeast androgen biosensor. The negative controls, performed with the empty p406CYC1 plasmid and with the DNA that was isolated from the empty yeast host (the nontransfected yeast cell), showed no PCR bands. PCR II (Fig. 1a) was performed with primers on the $C Y C l$ promoter and the $C Y C l$ terminator. As expected, it gave the specific 873-bp band with the reporter vector and the DNA that was isolated from the biosensor, because both contain the reporter construct with the yEGFP that was ligated between the $C Y C 1$ promoter and $C Y C 1$ terminator. The negative controls, performed with the empty p406-CYC1 plasmid and with the DNA that was isolated from the empty yeast host, did not show the reporter-specific 873-bp band. However, this PCR generated a 435-bp band with the DNA of the empty yeast host and the biosensor. This 435-bp band corresponds to the CYC gene of the yeast host itself and is therefore also a specific band. PCR III (Fig. 1b) was performed with the primers on the hAR gene. As expected, it gave the specific 2,763-bp band with the p403-GPD-hAR expression vector and the DNA that was isolated from the biosensor. In the negative control, performed with the DNA that was isolated from the yeast host, the receptor-specific 2,763-bp band was not present. These PCR controls demonstrate that all specific PCR bands can be seen, thus demonstrating that our yeast androgen bioassay contains the p403-GPD-hAR expression vector and the $\mathrm{p} 406-\mathrm{ARE}_{2}-\mathrm{CYCl}$-yEGFP reporter vector, both stably integrated in the yeast genome. 
a

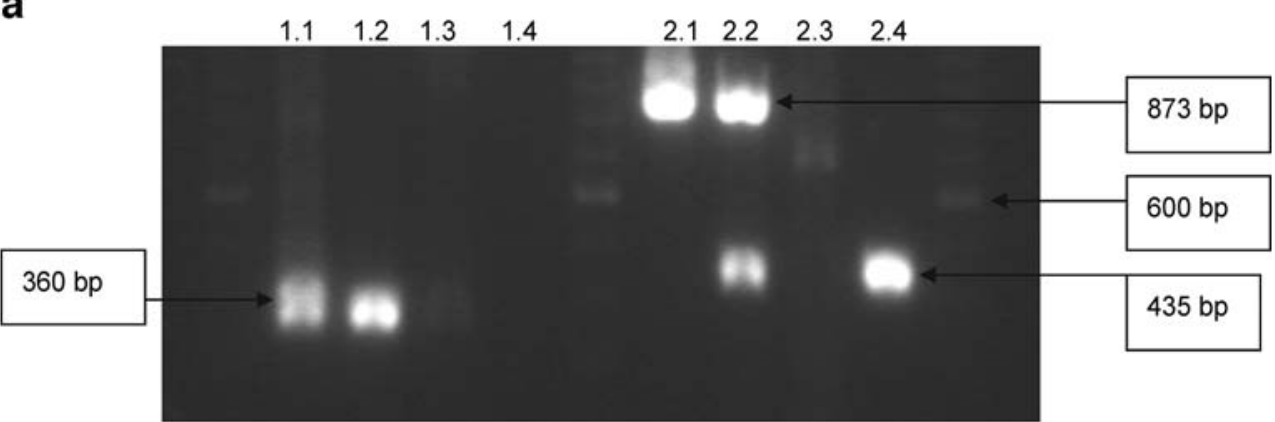

b

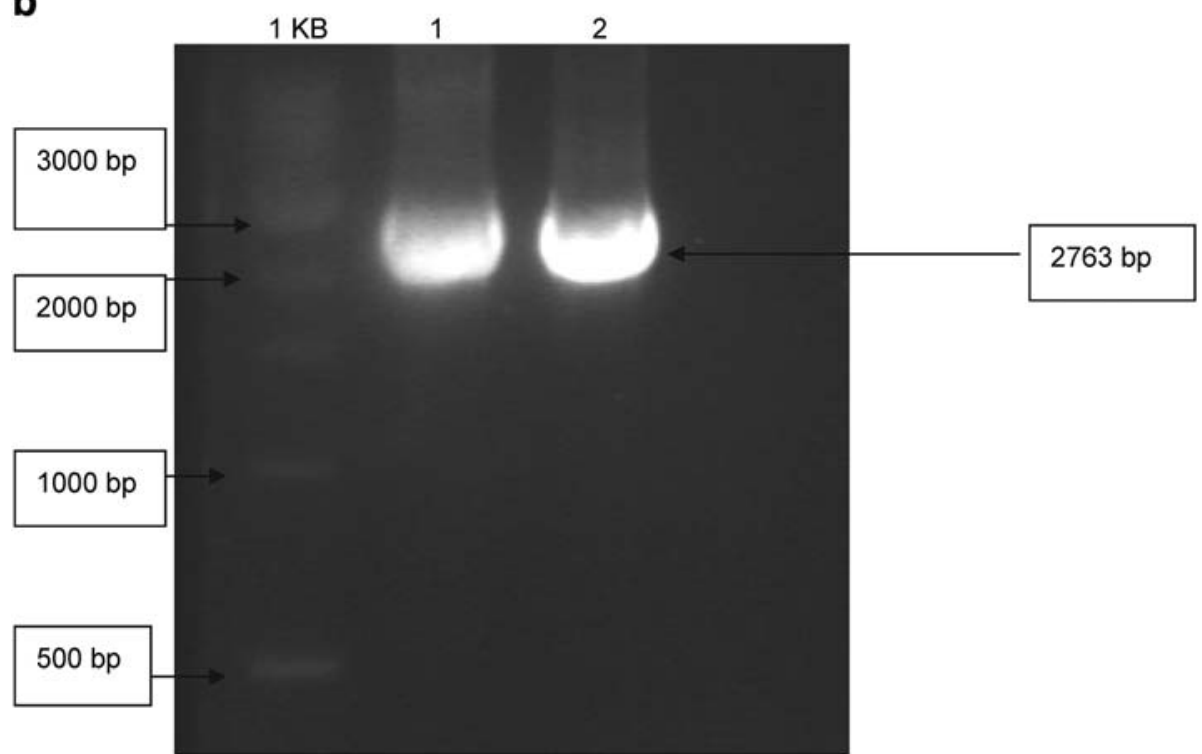

Fig. 1 PCR controls. The PCR controls were performed as described in "PCR controls." a Lanes 1, 6 and 11 contain a 100-bp ladder. PCR I was performed with primers on the backbone of the 406 plasmid and on the $\mathrm{ARE}_{2}$ sequence. Lanes $2-5$ are PCR I on the p406- $\mathrm{ARE}_{2}-$ CYC1-yEGFP reporter vector, the DNA that was isolated from the yeast transformant, the empty p406-CYC1 plasmid, and the DNA that was isolated from the empty yeast host (the nontransfected yeast cells), respectively. PCR II was performed with primers on the $\mathrm{CYCl}$

Dose-response curves obtained with the new yeast androgen bioassay

The dose-response curves for several natural and synthetic androgens are shown in Fig. 2. 5 $\alpha$-Dihydrotestosterone, $17 \beta$-testosterone and $17 \beta$-boldenone caused a dose-related increase in the production of yEGFP, demonstrating that these compounds are potent androgens. The bioassay showed a limit of detection of $3 \mathrm{nM}$ for $5 \alpha$-dihydrotestosterone with a dynamic range from 3 to $500 \mathrm{nM}$ and very low standard deviations (les than 3\%). The figure also shows that $17 \beta$-estradiol and progesterone give a response. The female hormone $17 \beta$-estradiol gives a full doseresponse curve, but the maximum of the curve is reached at a 500 times higher concentration than that of $17 \beta$ testosterone and is less steep. Progesterone gives a promoter and the $C Y C 1$ terminator. Lanes $7-11$ are PCR II on the reporter vector, the DNA from the yeast transformant, the empty p406CYC1 plasmid, and the DNA from the empty yeast host respectively. b Lane 1 contains a $1-\mathrm{kb}$ ladder. PCR III was performed with the primers on the human androgen receptor gene. Lanes 2-4 are PCR III on the p403-GPD-hAR expression vector, the DNA from the yeast transformant, and the DNA from the empty yeast host, respectively. $y E G F P$ yeast enhanced green fluorescent protein

response, but the maximum response is only about $35 \%$ of that of $17 \beta$-testosterone and is reached at a 25 times higher concentration. Both $17 \beta$-estradiol and progesterone are known to possess androgenic properties. Progesterone displays low binding to the androgen receptor [25] and shows androgenic effects in vivo [26]. According to [27], $17 \beta$-estradiol and progesterone showed androgenic activity in ten out of 11 and seven out of nine mammalian cell reporter gene (MCRG) systems, respectively. The corticosteroids corticosterone and dexamethasone showed no response in our assay.

Table 1 shows the calculated $\mathrm{EC}_{50}$, ie., the concentration giving a half-maximum response, and the RAP, defined as the ratio between the $\mathrm{EC}_{50}$ of $17 \beta$-testosterone and the $\mathrm{EC}_{50}$ of the compound, for several compounds. The yeast androgen bioassay showed good sensitivity towards all 


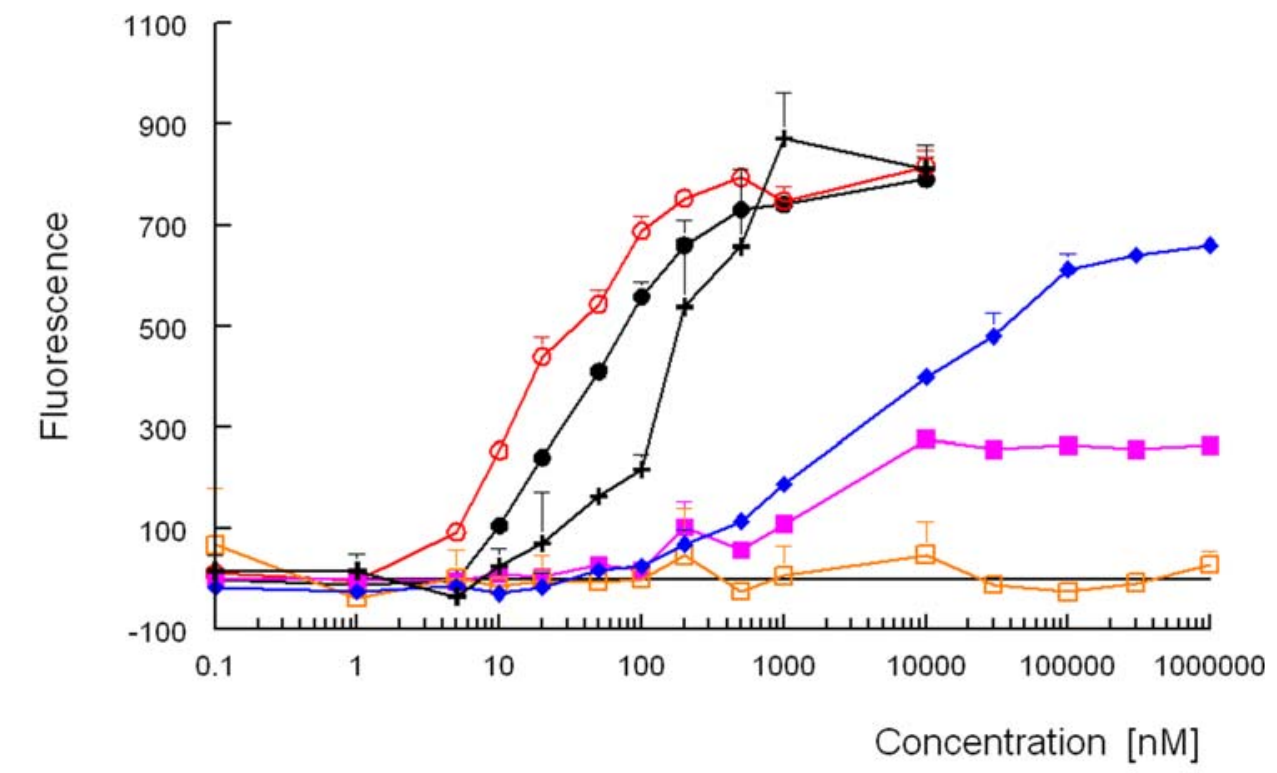

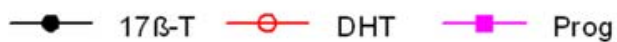

Fig. 2 Response of the yeast androgen biosensor to different substances. Exposure to $17 \beta$-testosterone, $5 \alpha$-dihydrotestosterone, progesterone, dexamethasone, $17 \beta$-estradiol, and $17 \beta$-boldenone was started by adding to $200 \mu \mathrm{L}$ of a yeast culture a $2-\mu \mathrm{L}$ aliquot of a stock solution of the compound in dimethyl sulfoxide (DMSO). Fluores-

androgens tested, with the following range of potencies: $5 \alpha$-dihydrotestosterone $>17 \beta$-trenbolone $>$ methyltrienolone $>$ tetrahydrogestrinone $>17 \beta$-testosterone $>17 \beta$ boldenone $>$ medroxyprogesterone acetate $>17 \beta$-estradiol $>$ progesterone. Steroids representative for other hormone receptors, like estrone, $17 \alpha$-estradiol, $17 \alpha$-ethynylestradiol, and diethylstilbestrol for the estrogen receptor and corticosterone and dexamethasone for the glucocorticoid receptor, showed no agonistic response. Only $17 \beta$-estradiol, progesterone and medroxyprogesterone acetate gave a clear agonistic response. However, these compounds are known to exert androgenic effects.

Compared with the NIH publication [27], there are a few discrepancies. According to [27], estrone is an androgen receptor agonist that showed androgenic activity in two out of two MCRG systems. However, some mammalian cells are able to convert estrone into $17 \beta$-estradiol and vice versa. This conversion is ascribed to $17 \beta$-hydroxysteroid dehydrogenase 3 and this enzyme is responsible for the high relative estrogenic potency (REP) of estrone in the estrogen bioassay with the T47-D breast cancer cells (ERCALUX test). In that test, the estrogenic potency of estrone was equal to that of $17 \beta$-estradiol and a REP of 1.0 was reported for estrone [10]. This probably explains why estrone gave a positive result for androgenic activity in two MCRG systems, but gave a negative result in our yeast androgen bioassay. Yeast is obviously not able to convert estrone into $17 \beta$-estradiol. The reported REP of 0.2 in our yeast estrogen biosensor corresponds nicely with the in

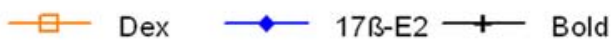

cence was determined after $24 \mathrm{~h}$ as described in "Streamlined yEGFP assay with the yeast androgen bioassay." Fluorescence signals are the mean of a triplicate with the standard deviation (SD). $17 \beta-T 17 \beta$ testosterone, DHT $5 \alpha$-dihydrotestosterone, Prog progesterone, Dex dexamethasone, 17 $\beta$-E2 17 $\beta$-estradiol, Bold 17 $\beta$-boldenone

vivo potency of this compound [28]. Dexamethasone was also described as an androgen receptor agonist in the NIH publication, showing androgenic activity in three out of four mammalian assays, but gave a negative result in our yeast androgen bioassay. However, these MCRG systems use an MMTV-Luc reporter construct or an ARE-Luc reporter construct. Both the MMTV and the ARE sequence are recognized by the glucocorticoid receptor and this means that the response found in these MCRG systems is probably due to crosstalk, as the glucocorticoid receptor is normally expressed in all cell types.

Dose-response curves obtained with the lacZ-based yeast androgen bioassay

Figure 3 shows the dose-response curves for several natural and synthetic androgens obtained with the lacZ-based yeast androgen bioassay. The assay was simplified in our laboratory by scaling it down to a 96-well format and the use of a $\beta$-galactosidase assay kit. With increasing $\beta$ galactosidase activity, the density of the yeast culture, measured at $630 \mathrm{~nm}$, dropped to about $50 \%$ (data not shown). Therefore, the measured â-galactosidase activity was corrected for the OD of the yeast culture. Table 2 shows the calculated $\mathrm{EC}_{50}$ and the corresponding RAP values. The data demonstrate that there is a good correlation between the $\mathrm{EC}_{50}$ values for androgens determined in our laboratory and those reported by Gaido et al. [29] in 1997. It seems that the lacZ-based yeast androgen 
Table $1 \mathrm{EC}_{50}$ concentrations and relative androgenic potencies $(R A P)$ of compounds in the yeast androgen biosensor expressing yeast enhanced green fluorescent protein in response to androgens

\begin{tabular}{|c|c|c|c|c|}
\hline Compound & $\begin{array}{l}\text { Qualitative response } \\
\text { for } \mathrm{AR} \text { agonism }^{\mathrm{a}}\end{array}$ & Comments $^{\mathrm{b}}$ & $\begin{array}{l}\mathrm{EC}_{50}(\mathrm{nM}) \text { in the yeast } \\
\text { androgen bioassay }\end{array}$ & $\mathrm{RAP}^{\mathrm{d}}$ \\
\hline $17 \beta$-Testosterone & Positive (11/11) & Strong AR agonist & 76 & 1.0 \\
\hline $5 \alpha$-Dihydrotestosterone & Positive $(21 / 21)$ & Strong AR agonist, weak ER agonist & 33 & 2.3 \\
\hline $17 \beta$-Boldenone & & & 510 & 0.15 \\
\hline $17 \beta$-Trenbolone & Positive & Binds strongly to AR & 52 & 1.5 \\
\hline Methyltrienolone & Positive $(8 / 8)$ & AR agonist & 54 & 1.4 \\
\hline Tetrahydrogestrinone & & AR agonist & 65 & 1.2 \\
\hline $17 \beta$-Estradiol & Positive $(10 / 11)$ & $\mathrm{AR}$ agonist and antagonist, strong ER agonist & 9,000 & 0.0084 \\
\hline Estrone & Positive $(2 / 2)$ & AR agonist, strong ER agonist & NR & NR \\
\hline $17 \alpha$-Estradiol & Negative $(1 / 1)$ & ER agonist & NR & NR \\
\hline $17 \alpha$-Ethynylestradiol & Negative $(1 / 1)$ & Strong ER agonist & NR & NR \\
\hline Diethylstilbestrol & Negative $(2 / 2)$ & Strong ER agonist & NR & NR \\
\hline 4-Hydroxytamoxifen ${ }^{\mathrm{e}}$ & Negative $(1 / 1)$ & ER antagonist & NR & NR \\
\hline Progesterone $\mathrm{f}^{\mathrm{f}}$ & Positive (7/9) & & 1,700 & 0.045 \\
\hline Medroxyprogesterone acetate & Positive (4/4) & Weak AR agonist & 1,500 & 0.051 \\
\hline Corticosterone & Negative $(1 / 1)$ & Binds weakly to AR & NR & NR \\
\hline Dexamethasone & Positive (3/4) & AR agonist & NR & NR \\
\hline Flutamide & Negative $(5 / 5)$ & $\mathrm{AR}$ antagonist & NR & NR \\
\hline 2,4,6-Tribromophenol & & & NR & NR \\
\hline BDE-19 & & & NR & NR \\
\hline 4-OH-BDE-17 & & & NR & NR \\
\hline
\end{tabular}

$A R$ androgen receptor, $E R$ estrogen receptor, $N R$ no response

${ }^{a}$ Qualitative response for AR agonism across all mammalian cell reporter gene studies (data obtained from [27])

${ }^{\mathrm{b}}$ Comments obtained from [27]

${ }^{\mathrm{c}}$ The $\mathrm{EC}_{50}$ is the concentration giving half-maximum response.

${ }^{\mathrm{d}}$ The RAP is defined as the ratio between the $\mathrm{EC}_{50}$ of $17 \beta$-testosterone and the $\mathrm{EC}_{50}$ of the compound.

${ }^{\mathrm{e}}$ This compound was toxic to yeast above $30 \mu \mathrm{M}$.

${ }^{\mathrm{f}}$ These compounds reach a maximum response that is lower than $70 \%$ of the maximum response obtained with $17 \beta$-testosterone. The maxima obtained with 4 -androstenedione and progesterone are about 40 and $35 \%$, respectively.

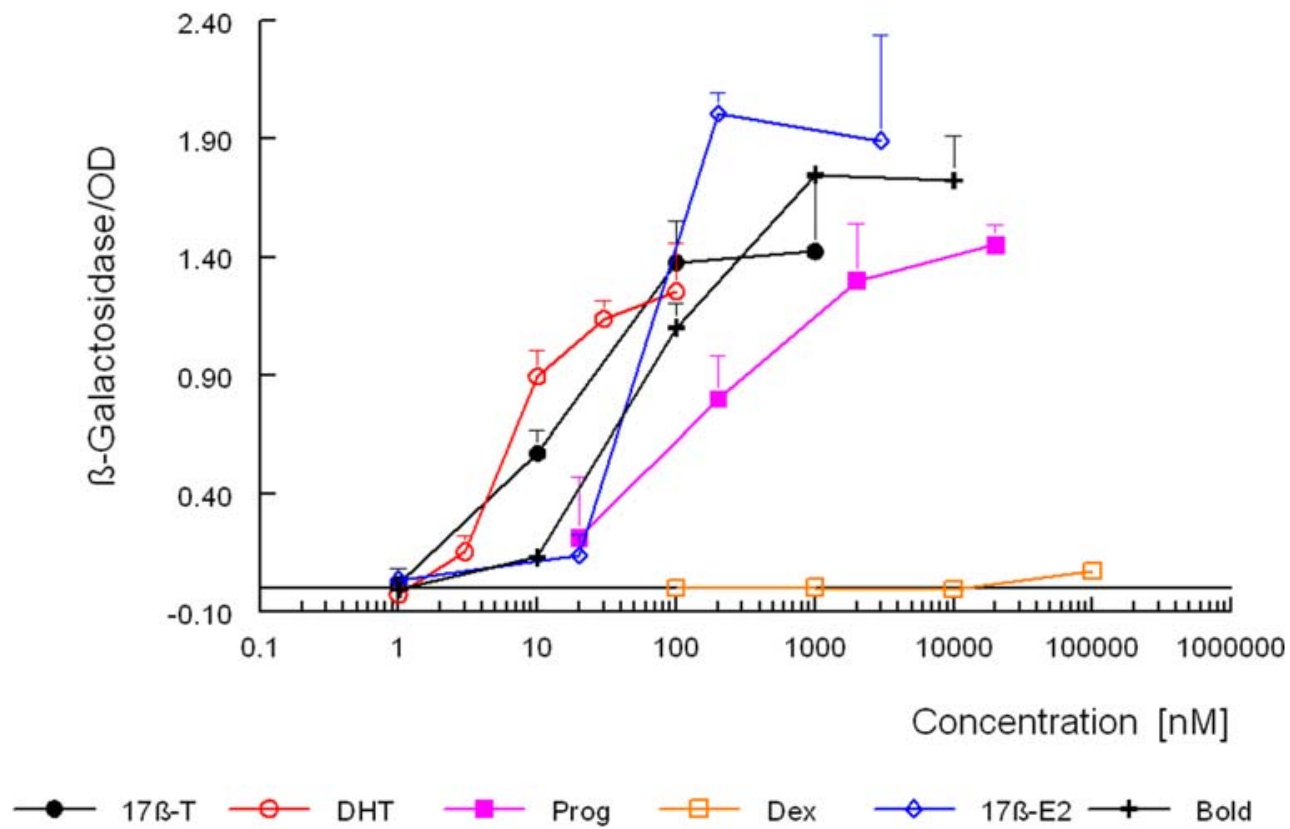

Fig. 3 Response of the McDonnell yeast androgen bioassay to different substances. Exposure to $17 \beta$-testosterone, $5 \alpha$-dihydrotestosterone, progesterone, dexamethasone, $17 \beta$-estradiol, and $17 \beta$-boldenone was started by adding to $200 \mu \mathrm{L}$ of a yeast culture a $2-\mu \mathrm{L}$ aliquot of a stock solution of

the compound in DMSO. The $\beta$-galactosidase activity was determined after $24 \mathrm{~h}$ and corrected for the optical density at $630 \mathrm{~nm}$ as described in "lacZ-based yeast androgen bioassay: $\beta$-galactosidase assay." Signals are the mean of a triplicate with the SD 
Table $2 \mathrm{EC}_{50}$ concentrations and RAPs of compounds in the yeast androgen bioassay expressing $\beta$-galactosidase in response to androgens

\begin{tabular}{llll}
\hline Compound & $\begin{array}{l}\mathrm{EC}_{50}(\mathrm{nM})^{\mathrm{a}} \text { by } \\
\text { Gaido et al. [29] }\end{array}$ & $\begin{array}{l}\mathrm{EC}_{50}(\mathrm{nM})^{\mathrm{b}} \text { in } \\
\text { our laboratory }\end{array}$ & $\mathrm{RAP}$ \\
\hline $17 \beta$-Testosterone & 4.7 & 11.5 & 1.0 \\
$5 \alpha$-Dihydrotestosterone & 3.5 & 4.9 & 2.3 \\
$17 \beta$-Boldenone & $\mathrm{ND}$ & 70 & 0.2 \\
$17 \beta$-Trenbolone & $\mathrm{ND}$ & 13 & 0.9 \\
Methyltrienolone & $\mathrm{ND}$ & 3.7 & 3.1 \\
Tetrahydrogestrinone & $\mathrm{ND}$ & 11.5 & 1.0 \\
$17 \beta$-Estradiol & 86.1 & 95 & 0.1 \\
$17 \alpha$-Estradiol & $\mathrm{ND}$ & $\mathrm{NR}$ & $\mathrm{NR}$ \\
Progesterone & 89.3 & 170 & 0.068 \\
Corticosterone & $\mathrm{ND}$ & $\mathrm{NR}$ & $\mathrm{NR}$ \\
Dexamethasone & $\mathrm{ND}$ & $\mathrm{NR}$ & $\mathrm{NR}$ \\
\hline
\end{tabular}

$N D$ not determined

${ }^{a}$ Values obtained by Gaido et al. [29], using the McDonnell yeast androgen bioassay

${ }^{\mathrm{b}}$ Values determined in our laboratory, using the McDonnell yeast androgen bioassay (see "Dose-response curves obtained with the lacZ-based yeast androgen bioassay")

bioassay, in terms of $\mathrm{EC}_{50}$ values, is 5-10 times more sensitive than our new bioassay. However, there was almost no difference in the limit of detection. Although the curves in the $\beta$-galactosidase assay go up at around $0.3 \mathrm{nM}$ and in the yEGFP assay at around $1 \mathrm{nM}$, the limit of detection is about $3 \mathrm{nM}$ for $5 \alpha$-dihydrotestosterone in both assay types. This is mainly because the standard deviations are much higher in the $\beta$-galactosidase assay. However, the curves in the $\beta$-galactosidase assay are much steeper and are thus responsible for the lower $\mathrm{EC}_{50}$ values. The steeper curves are probably due to using an enzyme as a marker, $\beta$ galactosidase compared with a yEGFP marker protein, and the expression of the RSP5 cofactor that enhances transcription activation in the lacZ-based yeast androgen bioassay. The dynamic range for $5 \alpha$-dihydrotestosterone in the McDonnell assay was from 3 to $100 \mathrm{nM}$ and is slightly smaller than the range of the new bioassay $(3-500 \mathrm{nM})$. There were also no great differences in the RAP values determined, although methyltrienolone was more potent in the lacZ-based bioassay. However, the new yEGFP bioassay is less sensitive for $17 \beta$-estradiol and progesterone: RAPs of 0.008 and 0.045 , respectively, and for the latter no full dose-response curve, compared with RAPs of 0.1 and 0.068 and full dose-response curves in the lacZ-based bioassay. This means that our new bioassay is more specific for detecting compounds with a pure androgenic mode of action. The main difference between the lacZ-based and our yEGFP biosassay is that protein RSP5, which is a counterpart of the mammalian RPF1, is overexpressed in the lacZ-based bioassay in order to enhance transcriptional efficacy. However, this cannot explain the observed difference with methyltrienolone, as according to Imhof and McDonnell [30], this did not alter the potency or specificity of the assay. In addition and in contrast to the lacZ-based yeast androgen bioassay there were no differences in the density of the yeast culture measured at $630 \mathrm{~nm}$ upon exposure to different compounds that induced

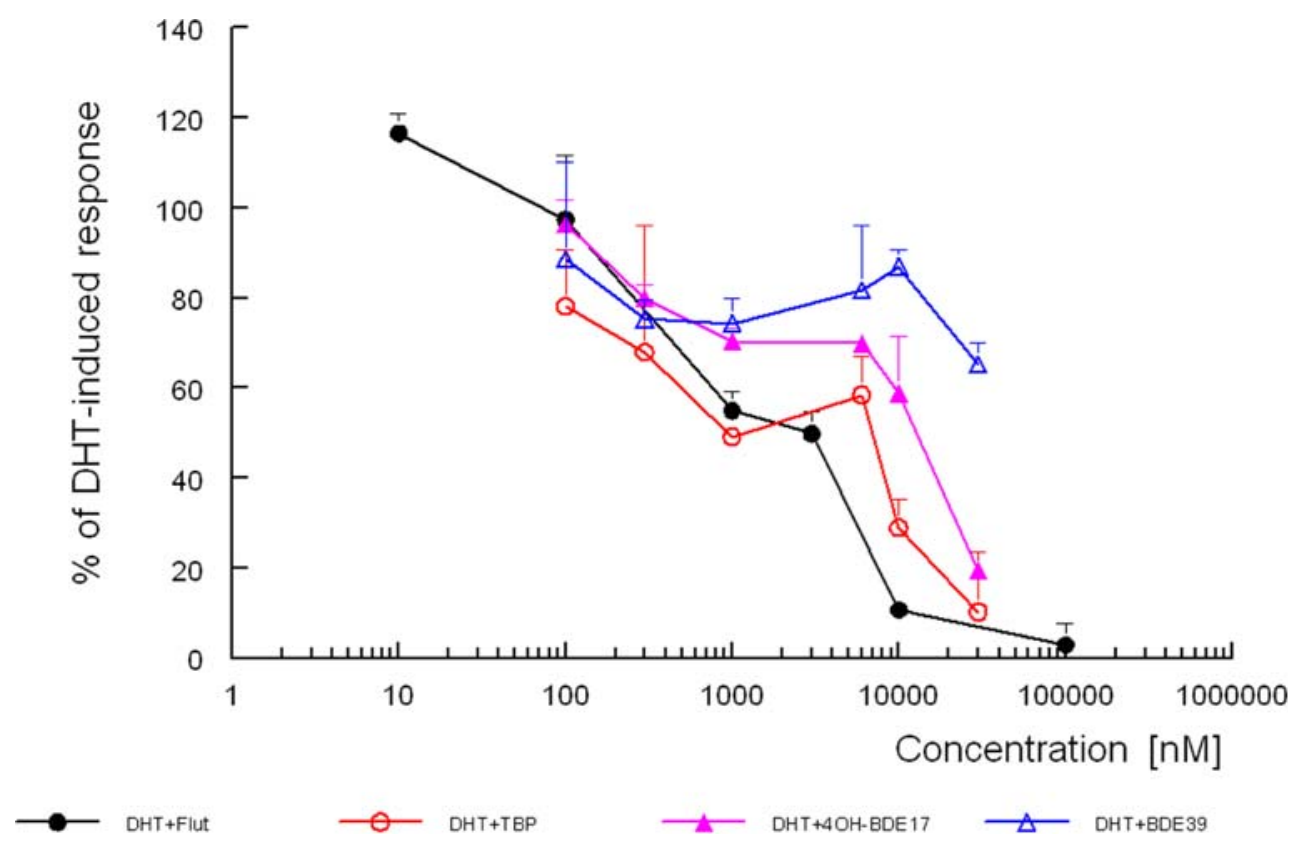

Fig. 4 Inhibition of a submaximal response obtained by $5 \alpha$-dihydrotestosterone with flutamide and three brominated flame retardants (BFRs). Coexposure to a concentration of $5 \alpha$-dihydrotestosterone that induced a submaximal response was started by adding to $200 \mu \mathrm{L}$ of a yeast culture, $1 \mu \mathrm{L}$ of a $5 \alpha$-dihydrotestosterone and $1 \mu \mathrm{L}$ of the BFR stock solution in

DMSO. Fluorescence was determined after $24 \mathrm{~h}$ as described in "Streamlined yEGFP assay with the yeast androgen bioassay." Fluorescence signals are the mean of a triplicate with the SD. TBP 2,4,6tribromophenol 
yEGFP expression, which indicates a decreased growth of yeast cells exposed to androgens in the lacZ-based yeast androgen bioassay. The only other known yeast androgen bioassay, one that uses luciferase as a reporter protein, displays similar characteristics in terms of specificity and was $5-10$ times more sensitive in terms of $\mathrm{EC}_{50}$ values [15]. However, this assay needs the correction of the same yeast strain that only and stably expressed luciferase as an external control to correct for and normalize the aspecific responses caused by variation in cell vitality due to matrix and analyte toxicity. Unorrected dose-response curves for $17 \beta$-testosterone displayed more than 10 times higher $\mathrm{EC}_{50}$ values. An earlier assay described by Lee et al. [31] in 2003 uses $\beta$-galactosidase, but only expresses the hinge-ligand binding domain of the androgen receptor.

\section{Antiandrogenic activity}

The specificity of the new yeast androgen bioassay was further demonstrated by the ability of antiandrogens to suppress the induction of yEGFP. Figure 4 shows the antiandrogenic activity of the known antagonist flutamide and three brominated flame retardants, BDE-39, TBP, and 4-OH-BDE-17. The antagonistic properties were examined by coexposure with a concentration of $5 \alpha$-dihydrotestosterone that induced a submaximal response $(50 \mathrm{nM})$. None of these four compounds were able to show an agonistic response (Table 1), but Fig. 4 clearly shows that all three were able to inhibit the response induced by $5 \alpha$-dihydrotestosterone. The $\mathrm{IC}_{50}$ value was about $1 \mu \mathrm{M}$ for flutamide, and TBP and 4-OH-BDE-17 were about as potent, while BDE-39 was clearly less antiandrogenic. Similar results were obtained with a human cell line. Only TBP was less potent in that test, but cytotoxicity of TBP could not be excluded [32].

\section{Conclusions}

A recombinant yeast cell was constructed that expresses the hAR and yEGFP as a reporter protein in response to androgens. Compared with other yeast androgen bioassays, this new biosassay showed a similar limit of detection and dynamic range. However, the measurement of the fluorescence (yEGFP) can be followed as a function of incubation time and is easier, quicker, and cheaper than the measurement of the $\beta$-galactosidase or the luciferase activity, which needs cell wall disruption and/or the addition of expensive substrates. Owing to the ease of the yEGFP measurement, standard deviations are generally less than 3\%. Moreover, the assay seems to be more robust and more specific for detecting compounds with a pure androgenic mode of action.
Brominated flame retardants with suspected antiandrogenic properties were able to inhibit the response obtained with $5 \alpha$-dihydrotestosterone, the most potent endogenous androgen, demonstrating that this yeast androgen bioassay is suited to detect compounds with both agonistic and antagonistic characteristics.

As all compounds tested were able to show either their agonistic or their antagonistic properties, neither the cell wall nor the cell membrane seemed to be an obstacle. As for the yeast estrogen bioassay, we validated this new yeast androgen bioassay according to international criteria, eg., the determination of the decision limit $(\mathrm{CC} \alpha)$ and the detection capability $(\mathrm{CC} \beta)$. The decision limit is then used to distinguish negative and suspect samples [16] (unpublished results). The assay was proven to be useful to detect the new designer steroid tetrahydrogestrinone in human urine [33] while prohormones with an androgenic mode of action, e.g., dehydroepiandrosterone, are not active in yeast-based bioassays and need metabolic activation before they can be detected [34]. Future work will include the validation of the assay for urine and feed and the screening of prohormones with and without metabolic activation. To mimic the in vivo metabolic activation, liver slices, liver cell lines, liver S9 enzymes, and pure enzymes will be used.

Acknowledgement This project was supported financially by the Dutch Ministry of Agriculture, Nature and Food Quality.

\section{References}

1. Pike MC, Spicer DV, Dahmoush L, Press MF (1993) Epidemiol Rev 15:17-35

2. Skakkebæk NE, Jørgensen N, Main KM, Rajpert-DeMeyts E, Leffers H, Andersson A, Juul A, Carlsen E, Mortensen GK, Jensen TK, Toppari J (2006) Int J Androl 29:2-11

3. Jobling S, Reynolds T, White R, Parker MG, Sumpter JP (1995) Environ Health Perspect 103:582-587

4. Jenkins RL, Wilson EM, Angus RA, Howell WM, Kirk M (2003) Toxicol Sci 73:53-59

5. Lemaire G, Terouanne B, Mauvais P, Michel S, Rahmani R (2004) Toxicol Appl Pharmacol 196:235-246

6. Henley DV, Lipson N, Korach KS, Bloch CA (2007) N Engl J Med 356:479-485

7. Garcia-Reyero N, Grau E, Castillo M, Lopez De Alda MJ, Barcelo D, Pina B (2001) Environ Toxicol Chem 20:1152-1158

8. Mueller SO (2002) J Chromatogr B 777:155-165

9. Sonneveld E, Riteco JAC, Jansen HJ, Pieterse B, Brouwer A, Schoonen WG, Van der Burg B (2006) Toxicol Sci 89:173-187

10. Hoogenboom LAP, De Haan L, Hooijerink D, Bor G, Murk AJ, Brouwer A (2001) Acta Pathol Microbiol Immunol Scand 109:101-107

11. Graumann K, Breithofer A, Jungbauer A (1999) Sci Total Environ 225:69-79

12. Witters HE, Vangenechten C, Berckmans P (2001) Water Sci Technol 43:117-123

13. Dhooge W, Arijs K, D'Haese I, Stuyvaert S, Versonnen B, Janssen C, Verstaete W, Comhaire F (2006) Anal Bioanal Chem 386:1419-1428 
14. Rehmann K, Schramm K, Kettrup AA (1999) Chemosphere 38:3303-3312

15. Michelini E, Leskinen P, Virta M, Karp M, Roda A (2005) Biosens Bioelectron 20:2261-2267

16. Bovee TFH, Bor G, Heskamp HH, Hoogenboom LAP, Nielen MWF (2006) Food Addit Contam 23:556-568

17. Haelens A, Verrijdt G, Callewaert L, Christiaens V, Schauwaers K, Peeters B, Rombauts W, Claessens F (2003) Biochemistry 369:141-151

18. Shaffer PL, Jivan A, Dollins DE, Cleassens F, Gewirth DT (2004) Proc Natl Acad Sci USA 101:4758-4763

19. Brodie J, McEwan IJ (2005) J Mol Endocrinol 34:603-615

20. Schoonen WG, Deckers G, De Gooyer ME, De Ries R, Kloosterboer HJ (2000) J Steroid Biochem Mol Biol 74:213-222

21. Blankvoort BMG, De Groene EM, Van Meeteren-Kreikamp AP, Witkamp RF, Rodenburg RJT, Aarts, JMMJG (2001) Anal Biochem 298:93-102

22. Willemsen P, Scippo M, Maghuin-Rogister G, Martial JA, Muller M (2005) Anal Bioanal Chem 382:894-905

23. Bovee TFH, Helsdingen JR, Koks PD, Kuiper HA, Hoogenboom LAP, Keijer J (2004) Gene 325:187-200
24. Cormack BP, Bertram G, Egerton M, Gow NAR, Falkow S, Brown AJP (1997) Microbiology 143:303-311

25. Fuhrman U, Krattenmacher R, Slater EP, Fritzmeier KH (1996) Contraception 54:243-251

26. Collins DC (1994)Am J Obstet Gynecol 170:1508-1513

27. NIH (2003) NIH publication no 03-4503

28. Bovee TFH, Helsdingen JR, Rietjens IMCM, Keijer J, Hoogenboom LAP (2004) J Steroid Biochem Mol Biol 91:99-109

29. Gaido KW, Leonard LS, Lovell S, Gould JC, Babaï D, Portier CJ, McDonnell DP (1997) Toxicol Appl Pharmacol 143:205-212

30. Imhof MO, McDonnell DP (1996) Mol Cell Biol 16:2594-2605

31. Lee HJ, Lee YS, Kwon HB, Lee K (2003) In Vitro Toxicol 17:237-244

32. Hamers T, Kamstra JH, Sonneveld E, Murk AJ, Kester MHA, Andersson PL, Legler J, Brouwer A (2006) Toxicol Sci 92:157-173

33. Nielen MWF, Bovee TFH, Van Engelen MC, Rutgers P, Hamers ARM, Van Rhijn JA, Hoogenboom LAP (2006) Anal Chem 78:424-431

34. Rijk J, Groot M, Peijnenburg A, Bovee T, Van Engelen M, Nielen M (2006) Paper presented at the 5th international symposium on hormone and veterinary drug residue analysis, Antwerp, Belgium 